\title{
ROS1 rearrangements in lung adenocarcinoma: prognostic impact, therapeutic options and genetic variability
}

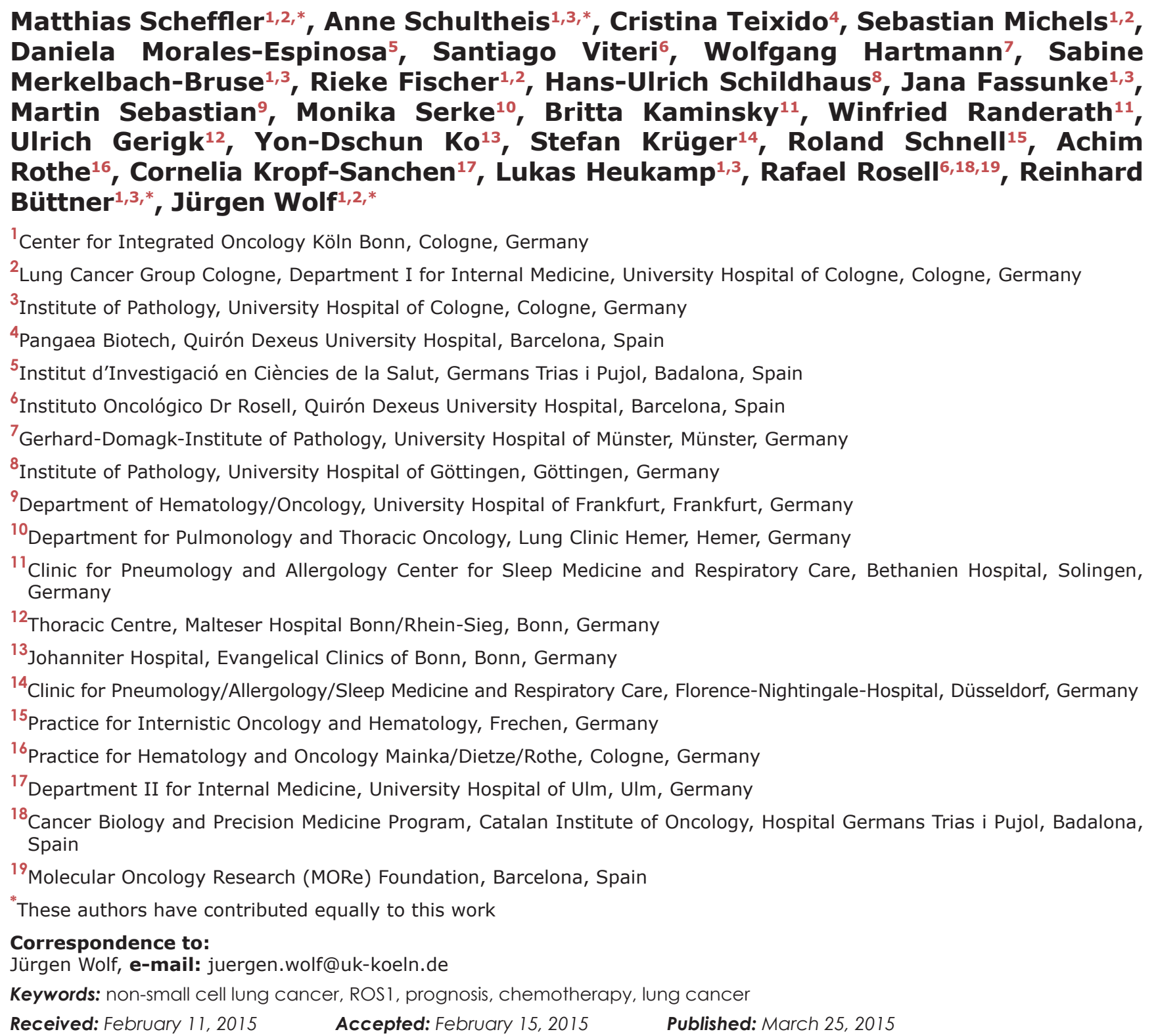

\section{ABSTRACT}

Background: While recent data show that crizotinib is highly effective in patients with ROS1 rearrangement, few data is available about the prognostic impact, the predictive value for different treatments, and the genetic heterogeneity of ROS1positive patients.

Patients and Methods: 1137 patients with adenocarcinoma of the lung were analyzed regarding their ROS1 status. In positive cases, next-generation sequencing (NGS) was performed. Clinical characteristics, treatments and outcome of these patients were assessed. Overall survival (OS) was compared with genetically defined subgroups of ROS1-negative patients. 
Results: 19 patients of 1035 evaluable (1.8\%) had ROS1-rearrangement. The median OS has not been reached. Stage IV patients with ROS1-rearrangement had the best OS of all subgroups (36.7 months, $p<0.001) .9$ of $14(64.2 \%)$ patients had at least one response to chemotherapy. Estimated mean OS for patients receiving chemotherapy and crizotinib was 5.3 years. Ten patients with ROS1-rearrangement $(52.6 \%)$ harbored additional aberrations.

Conclusion: ROS1-rearangement is not only a predictive marker for response to crizotinib, but also seems to be the one of the best prognostic molecular markers in NSCLC reported so far. In stage IV patients, response to chemotherapy was remarkable high and overall survival was significantly better compared to other subgroups including EGFR-mutated and ALK-fusion-positive NSCLC.

\section{INTRODUCTION}

Non-small cell lung cancer (NSCLC) is still the leading cause of cancer-related death in the western world [1]. Nevertheless, the identification of therapeutically targetable oncogenic driver aberrations has led to an improvement on the clinical outcome of genetically defined subgroups of patients, like those harboring a sensitizing mutation within the epidermal growth factor receptor gene $(E G F R)$ treated with EGFR-directed tyrosine kinase inhibitors (TKIs) or with rearrangements of the $A L K$ oncogene treated with specific TKIs [2-6]. Additionally, improved molecular diagnostics led to a genomics-based classifications of NSCLC [7].

Chromosomal rearrangements involving the ROSI gene (c-ros oncogene 1$)$ have recently been identified and described in $1-2 \%$ of patients with lung cancer $[8$, 9]. ROSI (chromosome 6q22) encodes a receptor tyrosine kinase which belongs to the insulin receptor family, with downstream signaling via the MAPK pathway through phosphorylation of RAS [10]. In lung cancer, ROS1 fusion partners include $F I G, C D 74, S L C 34 A 2$ and $S D C 4$, which lead to oncogenic transformation and constitutive kinase activity in cell culture and/or in vivo $[8,11,12]$. So far, no ligand for the ROS1 tyrosine kinase has been identified.

Preclinical data suggest that ROS1 can be targeted by ALK inhibitors due to highly similar tyrosine kinase domains [13]. These findings together with the clinical notion that the cohort of ROS1-rearranged patients share features with $A L K$-rearranged patients led to the discovery that crizotinib is an effective treatment option with high response rates [9]. Nevertheless, few is known about the prognostic value, the clinical presentation, the predictive value for different therapy regimens, and the genetic heterogeneity in terms of multiplex-sequencing of patients harboring ROS1 rearrangement.

We set out this study in order to genetically and phenotypically identify patients with $R O S 1$-rearranegments as part of an international, oligocentric prospective phase II trial to assess the response rates of patients with ROSIrearrangement treated with crizotinib (clinicaltrials.gov, NCT02183870), within a molecular screening network. The aim of this study was to detect the prevalence and incidence of ROS1 rearrangement in these patients, to analyze specific features of ROS1 rearrangement detection by fluorescence in situ hybridization (FISH), to describe their clinical and pathological characteristics, to assess co-occurring mutations measured by high-standard techniques (next-generation sequencing [NGS]), and to compare stage IV ROS1-positive patients with stage IV patients with other defined genetic aberrations regarding survival (i.e. $E G F R, E M L 4-A L K, F G F R 1, K R A S$ ).

\section{RESULTS}

\section{ROS1-rearrangement patterns}

The majority of the samples were biopsy specimens (i.e. core needle biopsies, ultrasound-guided transbronchial biopsies and cytology specimens). Of all ROS1-rearranged cases, only 1 sample was material from total tumor resection lobectomy. None of the ROS1 rearranged cases was a cytology specimen (i.e. blocked material from fine needle aspiration).

ROS1 status was evaluable in 1035 out of 1137 $(91.0 \%)$ patients, whereof 19 patients $(1.8 \%)$ had a ROSI rearrangement. ROS1 signals were homogeneously distributed in all analyzed tumors. The amount of cells showing aberrant signals ranged between $23 \%$ and $100 \%$ (mean $66 \%$, median 67\%). In all rearranged cases we observed an even signal distribution over the entire tumor with no "hot spot" areas. However, among different rearranged tumors, we observed a certain variation in the signal patterns. Some tumors showed only additional 3' signals with no or few split signals, indicating an unbalanced translocation. In contrast, other tumors showed a homogenous split signal pattern in all tumor cells (see Figure 1).

\section{Clinical presentation}

10 patients were male and 9 patients female. A summary of the clinical characterization is given in Table 1. The median age at diagnosis was 60 years (range, 26-87). In one patient, there were partially neuroendocrine patterns in the tumor. The majority of patients presented with stage IV disease at diagnosis $(n=14) .13$ patients 

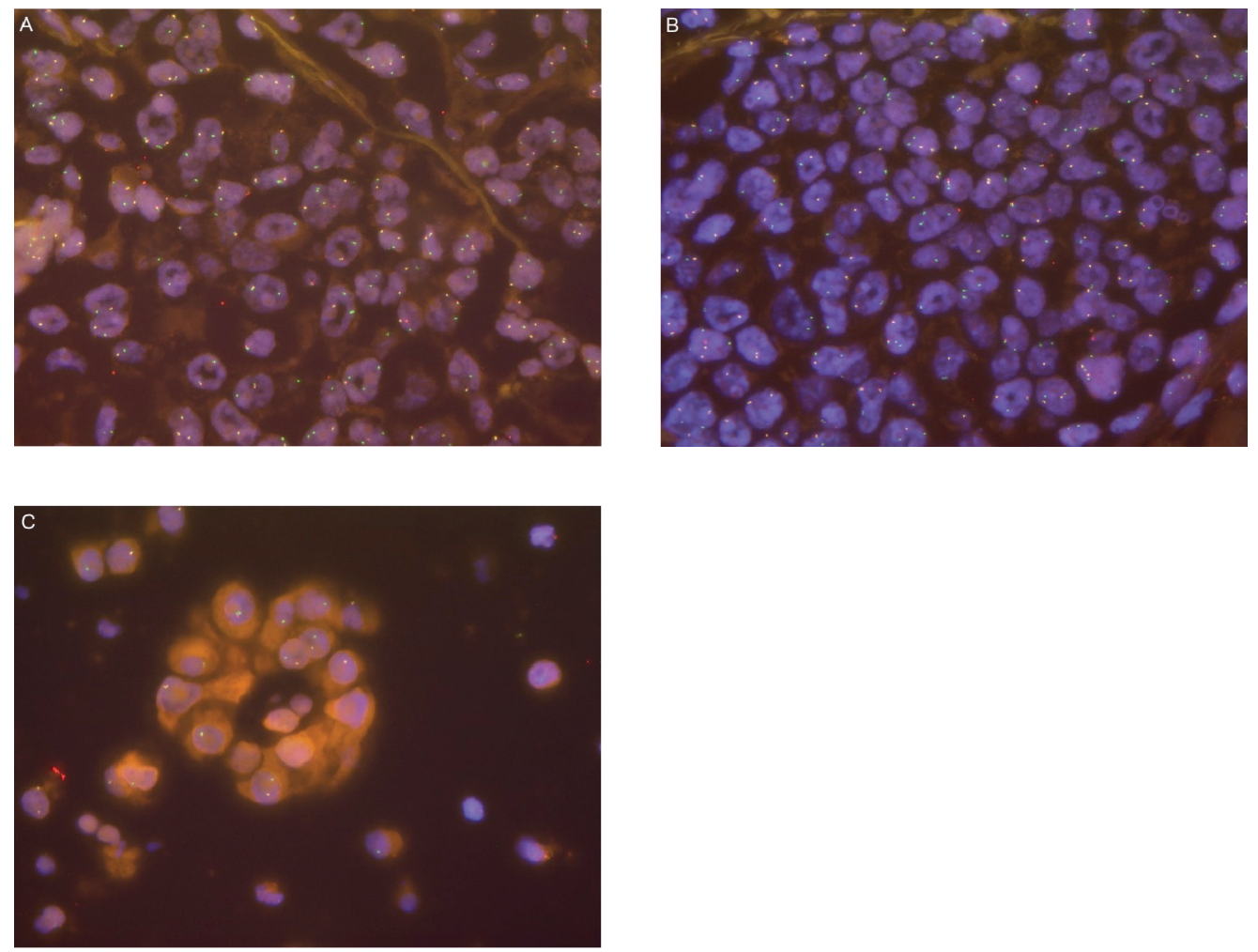

Figure 1: (A) ROS1-rearranged case with clear split signals and additional green signals. (B) ROS1-rearranged case with primarily additional green signals and few clear split signals. (C) ROS1-rearranged case with only additional green signals indicating an unbalanced translocation.

Table 1: Clinical characteristics of patients with ROS1-rearrangement $(n=19)$

\begin{tabular}{|c|c|c|c|}
\hline Characteristics & Number of patients & Years & $\%$ \\
\hline $\begin{array}{l}\text { Age at diagnosis } \\
\text { Mean } \\
\text { Standard deviation } \\
\text { Median } \\
\text { Range }\end{array}$ & 19 & $\begin{array}{c}58.6 \\
14.8 \\
60 \\
26-82\end{array}$ & 100 \\
\hline $\begin{array}{l}\text { Gender } \\
\text { Women } \\
\text { Men }\end{array}$ & $\begin{array}{c}9 \\
10\end{array}$ & & $\begin{array}{l}47.4 \\
52.6\end{array}$ \\
\hline $\begin{array}{c}\text { Smoking } \\
\text { Never } \\
\text { Former } \\
\text { Current }\end{array}$ & $\begin{array}{c}13 \\
3 \\
3\end{array}$ & & $\begin{array}{l}68.4 \\
15.8 \\
15.8\end{array}$ \\
\hline $\begin{array}{l}\text { UICC tumor stage } \\
\quad I \\
I I \\
I I I \\
I V\end{array}$ & $\begin{array}{c}2 \\
0 \\
3 \\
14\end{array}$ & & $\begin{array}{c}10.5 \\
0 \\
15.8 \\
73.7\end{array}$ \\
\hline
\end{tabular}


(68.4\%) were never-smokers, whereas 3 were active smokers and 3 patients had a smoking history. Patients with smoking history had a median of 40 pack-years (range, 30-45). The clinical and pathological presentation of each patient is listed in Table 2 .

\section{Co-occurring mutations detected by NGS}

15 of the $19(78.9 \%)$ detected patients could further be analyzed by NGS. In 7 (46.7\%), aberrations within the TP53 gene were detected: 5 patients $(33.3 \%)$ had the P72R-polymorphism, whereof one patient had also a E204* mutation, and one patient had a $\mathrm{K} 305^{*}$ as the only additional aberration. One patient had a R248L mutation co-occurring with a $M A P 2 K 1$ missense mutation $(\mathrm{K} 57 \mathrm{~N})$. Of the P72R patients, one had an EGFR mutation in exon 21 (P848L). All TP53 alterations were either known polymorphisms or inactivating and truncating mutations.

2 out of 17 patients analyzed with NGS or by Sanger sequencing (11.8\%) had BRAF mutations (G469S and an intron mutation c.1742-1 G > T, p.? which has not been described yet). One patient (6.7\%) showed a $M E T$ mutation (R988C), located within the juxtamembrane region. Taken together, in 10 of $15(66.7 \%)$ patients analyzed by NGS, further genetic aberrations were detected (see Table 2). Both BRAF mutations occurred in patients with a smoking history.

Table 2: Line listing of the patients

\begin{tabular}{|c|c|c|c|c|c|c|c|c|c|c|c|c|}
\hline Pat ID & Gender & $\begin{array}{c}\text { Age } \\
\text { (years) }\end{array}$ & $\begin{array}{c}\text { Initial } \\
\text { stage }\end{array}$ & $\begin{array}{c}\text { ROS1 } \\
\text { transl. } \\
(\%)\end{array}$ & $\begin{array}{l}\text { Additional } \\
\text { genetic } \\
\text { aberration }\end{array}$ & $\begin{array}{c}\text { Further } \\
\text { analyzed }\end{array}$ & $\begin{array}{l}\text { Pack- } \\
\text { years }\end{array}$ & $\begin{array}{c}\text { Systemic } \\
\text { therapy } \\
\text { lines-CTX }\end{array}$ & $\begin{array}{c}\text { BR } \\
\text { CTX }\end{array}$ & $\begin{array}{c}\text { Best } \\
\text { response } \\
\text { CTX under }\end{array}$ & $\begin{array}{c}\text { BR } \\
\text { crizotinib }\end{array}$ & $\begin{array}{c}\text { Overall } \\
\text { survival } \\
\text { (months) }\end{array}$ \\
\hline 02 & $\mathrm{~m}$ & 69 & IV & 100 & - & ALK FISH & 45 & 2 & $\mathrm{n} / \mathrm{a}$ & $\mathrm{n} / \mathrm{a}$ & $\mathrm{n} / \mathrm{a}$ & 36.72 \\
\hline 03 & $\mathrm{~m}$ & 55 & IV & 100 & TP53 P72R & NGS & 0 & 8 & PR & $\begin{array}{c}\text { CARBO/ } \\
\text { GEM/BEV } \\
(3 \mathrm{x})\end{array}$ & PR & $63.64 *$ \\
\hline 04 & $\mathrm{~m}$ & 62 & IV & 23 & - & NGS & 30 & 1 & SD & $\begin{array}{l}\text { CARBO/ } \\
\text { PEM }\end{array}$ & $\mathrm{n} / \mathrm{a}$ & $6.79 *$ \\
\hline 05 & $\mathrm{~m}$ & 50 & IV & 25 & $\begin{array}{c}E G F R \text { P } 848 \mathrm{~L}, \\
\text { TP53 P72R }\end{array}$ & NGS & 0 & 1 & $\mathrm{n} / \mathrm{a}$ & $\mathrm{n} / \mathrm{a}$ & $\mathrm{n} / \mathrm{a}$ & $1.41^{*}$ \\
\hline 06 & $\mathrm{~m}$ & 56 & IV & 25 & - & $\begin{array}{c}\text { NGS, } \\
\text { HER2 FISH }\end{array}$ & 0 & 1 & PR & CIS/PEM & $\mathrm{n} / \mathrm{a}$ & $12.20^{*}$ \\
\hline 07 & $\mathrm{~m}$ & 78 & IIIB & 50 & $\begin{array}{l}\text { TP53 E204*, } \\
\text { TP53 P72R }\end{array}$ & NGS & 0 & 1 & PD & $\mathrm{n} / \mathrm{a}$ & $\mathrm{n} / \mathrm{a}$ & 4.13 \\
\hline 08 & $\mathrm{f}$ & 26 & IV & 62 & TP53 K305* & $\begin{array}{c}\text { NGS, } \\
\text { HER2 FISH }\end{array}$ & 0 & 2 & PD & $\mathrm{n} / \mathrm{a}$ & $\mathrm{n} / \mathrm{a}$ & 2.95 \\
\hline 09 & $\mathrm{~m}$ & 52 & IA & 76 & - & NGS & 30 & $\mathrm{n} / \mathrm{a}$ & $\mathrm{n} / \mathrm{a}$ & $\mathrm{n} / \mathrm{a}$ & $\mathrm{n} / \mathrm{a}$ & $16.59 *$ \\
\hline 10 & $\mathrm{f}$ & 61 & IIIB & 83 & TP53 P72R & NGS & 0 & 1 & PR & (RCTX) & $\mathrm{n} / \mathrm{a}$ & $12.75^{*}$ \\
\hline 11 & $\mathrm{~m}$ & 31 & IV & 100 & - & NGS & 0 & 1 & PR & $\begin{array}{c}\text { CIS/PEM/ } \\
\text { BEV }\end{array}$ & $\mathrm{n} / \mathrm{a}$ & $21.25^{*}$ \\
\hline 12 & $\mathrm{f}$ & 87 & IV & 55 & MET R988C & $\begin{array}{c}\text { NGS, } \\
\text { HER2 FISH }\end{array}$ & 0 & 1 & PR & GEM & $\mathrm{n} / \mathrm{a}$ & $3.77 *$ \\
\hline 13 & $\mathrm{f}$ & 62 & IA & 65 & $B R A F \mathrm{G} 469 \mathrm{~S}$ & NGS & 40 & $\mathrm{n} / \mathrm{a}$ & $\mathrm{n} / \mathrm{a}$ & $\mathrm{n} / \mathrm{a}$ & $\mathrm{n} / \mathrm{a}$ & $41.64 *$ \\
\hline 14 & $\mathrm{f}$ & 69 & IV & 67 & TP53 P72R & NGS & 0 & 1 & PR & $\begin{array}{c}\text { CARBO/ } \\
\text { PACLI/ } \\
\text { BEV }\end{array}$ & PR & $13.34 *$ \\
\hline 15 & $\mathrm{f}$ & 54 & IIIA & 95 & - & $\begin{array}{l}\text { ALK, RET } \\
\text { FISH }\end{array}$ & 0 & $\mathrm{n} / \mathrm{a}$ & $\mathrm{n} / \mathrm{a}$ & $\mathrm{n} / \mathrm{a}$ & $\mathrm{n} / \mathrm{a}$ & 3.08 \\
\hline 16 & $\mathrm{f}$ & 50 & IV & 96 & - & NGS & 0 & 5 & PR & $\begin{array}{l}\text { GEM/CET, } \\
\text { DOCE/CET }\end{array}$ & PR & $78.59^{*}$ \\
\hline 17 & $\mathrm{~m}$ & 78 & IV & 74 & $\begin{array}{c}B R A F \\
\text { c. } 1742-1 \mathrm{G}>\mathrm{T}\end{array}$ & NGS & 40 & 1 & SD & PEM & $\mathrm{n} / \mathrm{a}$ & $3.02 *$ \\
\hline 18 & $\mathrm{~m}$ & 62 & IV & 26 & $\begin{array}{c}M A P 2 K 1 \\
\text { K57N, TP53 } \\
\text { R248L }\end{array}$ & NGS & 40 & 1 & SD & PEM & $\mathrm{n} / \mathrm{a}$ & $5.11 *$ \\
\hline
\end{tabular}

(Continued) 


\begin{tabular}{|c|c|c|c|c|c|c|c|c|c|c|c|c|}
\hline Pat ID & Gender & $\begin{array}{c}\text { Age } \\
\text { (years) }\end{array}$ & $\begin{array}{l}\text { Initial } \\
\text { stage }\end{array}$ & $\begin{array}{c}\text { ROS1 } \\
\text { transl. } \\
(\%)\end{array}$ & $\begin{array}{l}\text { Additional } \\
\text { genetic } \\
\text { aberration }\end{array}$ & $\begin{array}{l}\text { Further } \\
\text { analyzed }\end{array}$ & $\begin{array}{l}\text { Pack- } \\
\text { years }\end{array}$ & $\begin{array}{c}\text { Systemic } \\
\text { therapy } \\
\text { lines - CTX }\end{array}$ & $\begin{array}{c}\text { BR } \\
\text { CTX }\end{array}$ & $\begin{array}{c}\text { Best } \\
\text { response } \\
\text { CTX under }\end{array}$ & $\begin{array}{c}\text { BR } \\
\text { crizotinib }\end{array}$ & $\begin{array}{r}\text { Overall } \\
\text { survival } \\
\text { (months) }\end{array}$ \\
\hline 19 & $\mathrm{f}$ & 51 & IV & 96 & - & $\begin{array}{c}\text { EGFR, } \\
\text { KRAS, } \\
\text { BRAF, ALK }\end{array}$ & 0 & 5 & PR & DOCE & PR & $33.25 *$ \\
\hline 20 & f & 60 & IV & 70 & - & $\begin{array}{c}\text { EGFR, } \\
\text { ALK, } \\
\text { KRAS, } \\
\text { BRAF, RET }\end{array}$ & 0 & 3 & PR & CIS/PEM & PR & 27.67 \\
\hline
\end{tabular}

Abbreviations: $\mathrm{m}=$ male, $\mathrm{f}=$ female; $\mathrm{NGS}=$ next-generation sequencing, $\mathrm{FISH}=$ flourescence in situ hybridization; $\mathrm{CTX}=$ chemotherapy, $\mathrm{BR}=$ best response, $\mathrm{PR}=$ partial response, $\mathrm{SD}=$ stable disease, $\mathrm{PD}=$ progressive disease; $\mathrm{CARBO}=$ carboplatin, GEM = gemcitabine, BEV = bevacitzumab, PEM = pemetrexed, RCTX = combined radio-chemotherapy, PACLI = paclitaxel, CET $=$ cetuximab, DOCE $=$ docetaxel.

*for OS: ongoing. NGS: panel with 102 amplicons and 14 genes.

In all four patients without NGS analysis the $A L K$ status analysis was performed using FISH. None of them harbored a translocation. RET status was negative in the two patients analyzed. Sanger sequencing did not reveal any other genetic aberrations.

\section{Survival analysis}

Median follow-up time (see supplementary data) was 16.6 months (95\% CI, 9.3-23.9 months). For patients with ROS1-rearrangement, the median OS was not reached (see Figure 2A). The estimated mean survival time was 51.1 months (95\% CI, 32.1-70.0 months).

Patients with stage IV $(n=14)$ were further compared with 115 stage IV patients comprising 38 patients with $E G F R$ mutation treated with erlotinib and/or gefitinib and/or afatinib ( $+/-$ cetuximab), 13 patients with $A L K$ rearrangement treated with crizotinib and/or ceritinib, 32 patients with $K R A S$ mutations and 32 patients with squamous-cell carcinoma and FGFR 1 amplification (see Supplementary Figure 1). Survival for the ROS1-positive patients was significantly better than in the comparison group (36.7 months vs 17.5 months, $p=0.005$ ). Median overall survival for the ROS1-patients who did not receive crizotinib treatment $(n=9)$ was 36.7 months, whereas the median for the five patients receiving crizotinib has not been reached (estimated mean OS, 65.9 months [95\% CI, 44.3 - 87.5 months], see Supplementary Figure 2). Due to the small sample-size and the low prevalence of events, no statistical significance between ROS1 stage IV patients with or without crizotinib treatment ( $p=0.279$, see supplement) could be found.

Compared with genetically predefined subgroups, patients with ROS1-rearrangement had the best OS ( $p \leq$ 0.001 , see Figure 2B and Table 3 ). OS was significantly prolonged compared to EGFR-mutated patients (36.7 vs. 25.3 months, $p=0.047$ ) and to $A L K$-rearranged patients (36.7 vs. 23.9 months, $p=0.026$ ), both treated with targetspecific therapy. Taken both, EGFR-positive and ALKpositive patients together, their OS was 24.2 months $(95 \%$ CI, 20.9-27.5 months) and remained significantly shorter than for ROS1-rearranged patients $(p=0.033)$.

\section{Treatment outcomes}

Of the 14 stage IV patients, 12 were evaluable for outcome analysis (one had an individual treatment approach with combining systemic therapy with local procedures, one was lost to follow-up after irradiation of cerebral metastasis). Two stage IIIB patients were taken into analysis. The 14 patients received between one and 8 chemotherapy lines respectively (median $=1$, see Table 2 ). Of them, 9 patients $(64.3 \%)$ had at least one radiological response to chemotherapy, $3(21.4 \%)$ had stable disease as best outcome and $2(14.3 \%)$ did not respond to chemotherapy (see Supplementary Figure 3A). Table 2 shows the different outcomes of the patients. Both patients not responding to treatment had additional truncating TP53 mutations, possibly indicating that p53 inactivation might be a surrogate marker for chemoresistance of ROS1-positive tumors. Due to the small number of patients without benefit from chemotherapy, we did not check for a correlation of the percentage of translocated tumor cells and clinical outcome.

Supplementary Table 1 lists the used regimen and their outcomes. Noteworthy, while platinum/pemetrexed combinations showed high response rates with four out of five times used, the commonly used first-line therapy of platinum/paclitaxel only led to one response in six applications (see Supplementary Figure 3B and Supplementary Table 1). In all cases, treatment with erlotinib led to primary progression $(n=3)$. In three cases, progression developed under bevacizumab maintenance therapy after initial response (data not shown).

Five patients received crizotinib treatment; all of them responded impressively to monotherapy (see Figure 2C). So far only one patient died under therapy, whereas the remaining four are still ongoing under therapy.

\section{DISCUSSION}

To our knowledge, this study is the first analysis of Caucasian ROS1-rearranged patients demonstrating an OS advantage compared to other patients with NSCLC, even 

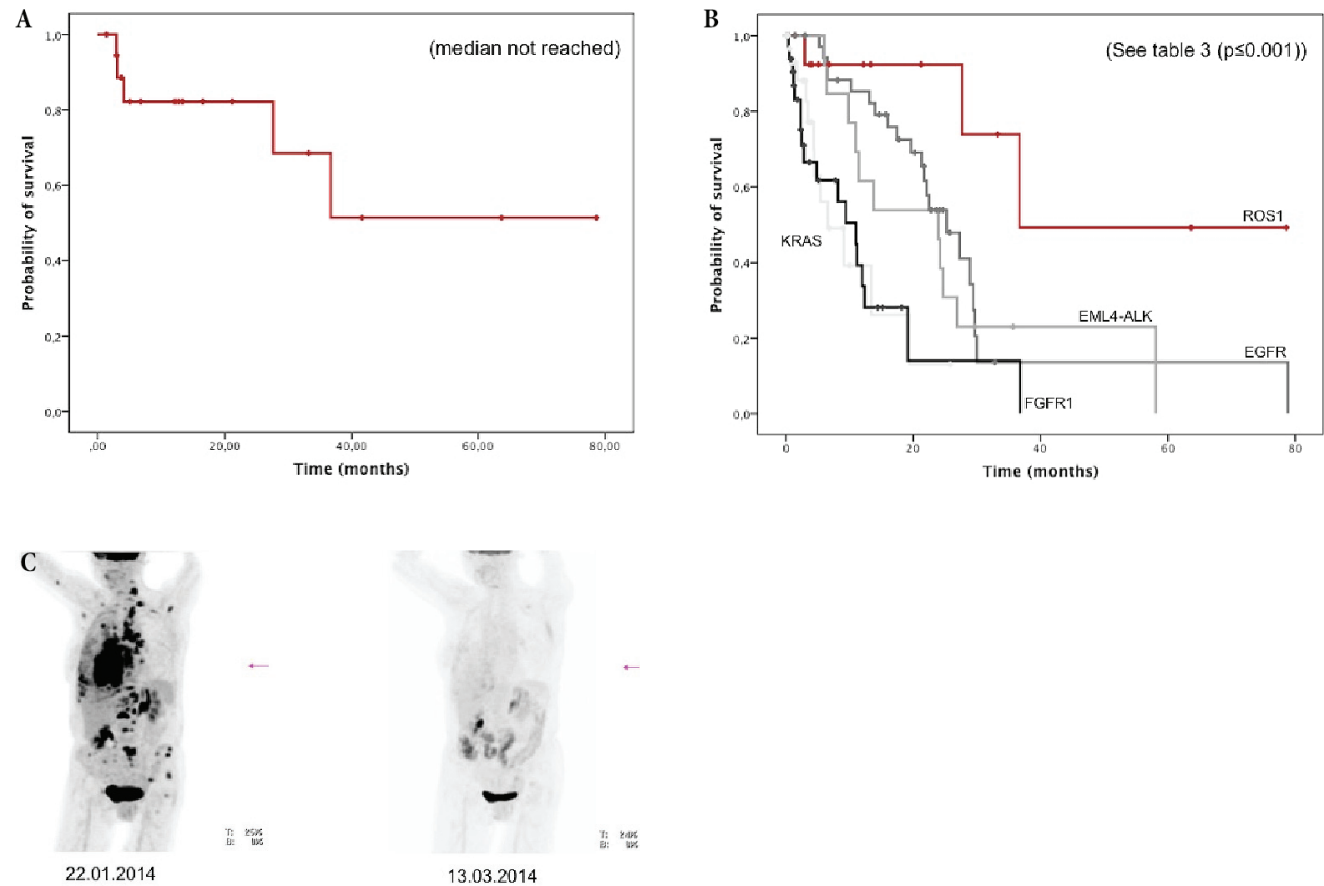

Figure 2: (A) Overall survival of all patients with ROS1-rearrangement ( $n=19)$. (B) Overall survival of stage IV with ROS1rearrangement $(n=14)$ and comparison with other genetically defined stage IV subgroups $(n=115)$. (C) Example of impressive metabolic response in a patient with ROS1-rearrangement treated with crizotinib at baseline and after two months of therapy.

Table 3: Summary of the subgroups used for comparison of OS

\begin{tabular}{|l|c|c|c|c|c|}
\hline \multicolumn{1}{c}{ ROS1 } & EGFR & EML4-ALK & KRAS & FGFR1 \\
\hline Patients (n) & 14 & 38 & 13 & 32 & 32 \\
\hline Median age (range) & $58(25-87)$ & $70(30-86)$ & $42(28-70)$ & $64(35-83)$ & $68(47-80)$ \\
\hline $\begin{array}{l}\text { Median OS months } \\
\text { (95\% CI) }\end{array}$ & 36.7 (n. a.) & $25.3(19.3-31.3)$ & $23.9(8.9-38.9)$ & $6.6(1.2-12.0)$ & $11.0(5.6-16.4)$ \\
\hline
\end{tabular}

when compared to targeted-treated EGFR-mutated and/ or $A L K$-rearranged patients. Further, this analysis suggests a potential benefit of chemotherapy for this subgroup of NSCLC patients regarding OS and response and stays in line with recent reports of the high efficacy of crizotinib treatment for these patients [9, 14-17]. Taken together, due to high response rates under both "classic" cytotoxic therapy and targeted therapy with crizotinib for stage IV patients ROSIrearrangement seems to repesent one of the best prognostic factors in NSCLC reported so far. Estimated mean survival times for all patients are in the range of years, and until today, no median OS has been reached, neither for the entire population nor for the stage IV patients receiving crizotinib.

Due to its exploratory character, this analysis suffers some limitations: The number of patients described is small, and no power calculation has been performed a priori. By nature, all the analyses presented here were retrospective, and pooling the treatment regimens and the resulting response rates is not comparable to outcomes in prospective clinical trials. Nevertheless, given the low frequency of $1.8 \%$ in 1035 screened patients and the very recent discovery of this aberration, such retrospective analyses are needed to gain more insights in the clinical course of these patients. Clinical trials to evaluate the efficacy of crizotinb treatment prospectivly for patients with ROS1-rearrangement are ongoing, and these data will be available in the near future.

Importantly and in some contrast to published literature [9], our data show that $\mathrm{ROS1-rearrangements}$ are not mutually exclusive with other transformationassociated genetic aberrations, as the majority of the patients presented with additional mutations. Beside mutations in BRAF, MET, and MAP2K1, we found a large variety of mutations affecting TP53. In two cases, truncating mutations of TP53 co-occurred with progressive disease under chemotherapy, whereof one patient, a 26-year old female patient, also presented with a partial neuroendocrine histology. Analysis of larger series of ROS1 positive patients in the future will elucidate whether these additional aberrations might play a role in the development of resistance. 
In $A L K$-rearaanged patients, pemetrexed is an efficient treatment choice [18]. While the efficacy of crizotinib in ROS1-rearranged patients has been recently shown [16], our dataset also suggests a benefit for pemetrexed-containing regimens in these patients. Therefore, drug development comprises both genetic subgroups [19]. Surprisingly, paclitaxel-containing platinum therapy seems to underperform in this patient group. Although the interpretation of this observation clearly is limited by the low patient number, it will be interesting to see if the choice of the primary platinumbased chemotherapy regimen has an impact on outcome.

Taken together, ROS1-rearranged patients represent a unique subgroup of NSCLC patients, with a relatively good prognosis, a remarkable good outcome under different regimens of chemotherapy and dramatic responses under crizotinib. Future analysis will reveal more insights regarding the role of additional genetic aberrations in acquired resistance and differences in the efficacy of distinct chemotherapeutic regimens.

\section{METHODS}

\section{Patients}

This study was performed within a collaborative health care provider network for comprehensive molecular diagnostics of lung cancer in Cologne, Germany (Network Genomic Medicine [NGM], based at the Center for Integrated Oncology Köln-Bonn [CIO], Cologne, Germany), where samples of 1024 patients were analyzed, and in Barcelona, Spain, where 113 samples were screened for ROS1-status. The screening process was performed in order to detect patients who might participate in the aforementioned clinical trial. The trial has been approved by local auhorities and the responsible ethics committees. Screening procedures were conducted in concordance with the local ethical guidelines and were reviewed by the institutional ethics committee. All patients consented to be contacted after diagnosis and to provide information about the clinical history and outcome. Insight into their medical records was obtained. The present study covers a timeframe from August 2012 to April 2014. There was no preselection of patients regarding stage or clinical presentation.

Within the same timeframe, we collected data from patients without ROS1-rearrangement, who provided written informed consent to have their data analyzed, but with other defined aberrations. As ROS1-rearrangement most probably occurs in patients without smoking history [9], and given the fact that NSCLC in neversmokers differs heavily from those of smokers in terms of mutational variability [20], we chose $A L K$-rearranged and $E G F R$-mutated patients with similar smoking habits as the best fitting control group. For both groups, patients were only taken into analysis if they had received treatment with at least one therapy-line with TKIs (i. e., erlotinib, gefitinib, afatinib, AZD9291 for EGFR, crizotinib and/or ceritinib for EML4-ALK), representing the subgroups of NSCLC patients so far with the best overall survival (OS) in stage IV NSCLC [7]. We also analyzed patients with $K R A S$ mutations to provide a group without any targeted therapy option, and FGFRI-amplified squamous-cell carcinoma patients as a comparator smoking associated lung cancer [21].

\section{Samples and immunohistochemistry}

Tumor tissue was fixed in buffered formalin and embedded in paraffin blocks. All primary diagnoses were reviewed by two experienced pathologists. Morphologic features, e.g. size of nuclei, nucleus/ cytoplasm ratio and chromatin structure were evaluated on haematoxylin-eosin slides. To confirm the diagnosis ancillary immunohistochemical stainings were made, e.g. cytokeratins (CK5/6, CK7, p40) as well as TTF1 (thyroid transcription factor 1). Tumor diagnoses were made in accordance to the current WHO classification system [22].

\section{FISH assay}

For FISH, three to four $\mu \mathrm{m}$ tissue sections were mounted on sialinized slides and hybridized overnight with the ZytoLight ${ }^{\circ}$ SPEC ROS1 Dual Color Break Apart Probe (ZytoVision, Bremerhaven, Germany). The 3 ' ROS1 probe was labeled with ZyGreen ${ }^{\mathrm{TM}}$ and the $5^{\prime}$ ROS1 probe was labeled with ZyOrange ${ }^{\mathrm{TM}}$. An exact protocol about the procedures is given in the supplementary file.

Tumors were defined as ROS1 rearranged when having $\geq 20 \%$ of tumor cells harboring aberrant signals.

\section{Next-generation sequencing (NGS)}

A more detailed protocol of tissue preparation for NGS is added as a supplementary file. Targeted next generation sequencing (NGS) was performed on all FFPE samples. Isolated DNA $(<0.5-200 \mathrm{ng} / \mu \mathrm{l})$ was amplified with an in-house specified, customized Ion AmpliSeq Primer Pool (Lifetechnologies, Carlsbad, USA). The panel comprises 102 amplicons of 14 different genes. PCR products were ligated to adapters and enriched for target regions using the Ion AmpliSeq Panel ${ }^{\mathrm{TM}}$ Library kit according to manufacturer's instructions (Lifetechnologies). The generated libraries were pooled equimolarly for amplicon sequencing to a concentration of $3 \mathrm{nM}$ of each sample to counterbalance differences in sample quality. Sequencing was performed on the Illumina MiSeq benchtop sequencer (Illumina, San Diego, USA). Results were visualized in the Integrative Genomics Viewer (IGV) and then manually analyzed. A 5\% cutoff for variant calls was used and results were only interpreted if the coverage was $>200$. 


\section{Clinical parameters}

Age, gender, and tumor stage at diagnosis according to the UICC classification were assessed. Smoking status, medical history regarding past cancer therapies, and outcome to treatments were analyzed. For smoking status, pack-years were annotated. The following qualitative attribution was assessed: Patients with less than 100 cigarettes in their lifetime were considered as never smokers, patients with more than 100 cigarettes, who quit smoking at least one year before first diagnosis of lung cancer were considered former smokers, and patients with a smoking history of more than one pack-year who continued smoking for a period shorter than one year before diagnosis were considered current smokers.

\section{Statistics}

Qualitative variables were summarized by count and percentage, quantitative variables (i.e. age) by mean, standard deviation, median and range. Distribution of time to event was described by the Kaplan-Meier curve and compared between groups by the log-rank test, giving the $95 \%$ confidence interval $(95 \% \mathrm{CI})$. Association of qualitative variables was tested for by chisquare or Fisher's exact test, contingent on distributional assumptions. Overall survival (OS) was defined as the time period from the date of first diagnosis until death. Patients who were still alive at the data cut-off were censored.

\section{REFERENCES}

1. Siegel R, Ma J, Zou Z, Jemal A. Cancer statistics. CA Cancer J Clin. 2014; 64:9-29.

2. Mok TS, Wu YL, Thongprasert S, Yang CH, Chu DT, Saijo N, Sunpaweravong P, Han B, Margono B, Ichinose Y, Nishiwaki Y, Ohe Y, Yang JJ, Chewaskulyong B, Jiang H, Duffield EL, et al. Gefitinib or carboplatin-paclitaxel in pulmonary adenocarcinoma. The New England journal of medicine. 2009; 361:947-957.

3. Rosell R, Carcereny E, Gervais R, Vergnenegre A, Massuti B, Felip E, Palmero R, Garcia-Gomez R, Pallares C, Sanchez JM, Porta R, Cobo M, Garrido P, Longo F, Moran T, Insa A, et al. Erlotinib versus standard chemotherapy as first-line treatment for European patients with advanced EGFR mutation-positive non-small-cell lung cancer (EURTAC): a multicentre, open-label, randomised phase 3 trial. The lancet oncology. 2012; 13:239-246.

4. Kwak EL, Bang YJ, Camidge DR, Shaw AT, Solomon B, Maki RG, Ou SH, Dezube BJ, Janne PA, Costa DB, Varella-Garcia M, Kim WH, Lynch TJ, Fidias P, Stubbs H, Engelman JA, et al. Anaplastic lymphoma kinase inhibition in non-small-cell lung cancer. The New England journal of medicine. 2010; 363:1693-1703.
5. Sequist LV, Yang JC, Yamamoto N, O’Byrne K, Hirsh V, Mok T, Geater SL, Orlov S, Tsai CM, Boyer M, Su WC, Bennouna J, Kato T, Gorbunova V, Lee KH, Shah R, et al. Phase III study of afatinib or cisplatin plus pemetrexed in patients with metastatic lung adenocarcinoma with EGFR mutations. J Clin Oncol. 2013; 31:3327-3334.

6. Shaw AT, Kim DW, Mehra R, Tan DS, Felip E, Chow LQ, Camidge DR, Vansteenkiste J, Sharma S, De Pas T, Riely GJ, Solomon BJ, Wolf J, Thomas M, Schuler M, Liu G, et al. Ceritinib in ALK-rearranged non-small-cell lung cancer. N Engl J Med. 2014; 370:1189-1197.

7. Clinical Lung Cancer Genome P, Network Genomic M. A genomics-based classification of human lung tumors. Sci Transl Med. 2013; 5:209ra13.

8. Takeuchi K, Soda M, Togashi Y, Suzuki R, Sakata S, Hatano S, Asaka R, Hamanaka W, Ninomiya H, Uehara H, Lim Choi Y, Satoh Y, Okumura S, Nakagawa K, Mano H, Ishikawa Y. RET, ROS1 and ALK fusions in lung cancer. Nat Med. 2012; 18:378-381.

9. Bergethon K, Shaw AT, Ou SH, Katayama R, Lovly CM, McDonald NT, Massion PP, Siwak-Tapp C, Gonzalez A, Fang R, Mark EJ, Batten JM, Chen H, Wilner KD, Kwak EL, Clark JW, et al. ROS1 rearrangements define a unique molecular class of lung cancers. J Clin Oncol. 2012; 30:863-870.

10. Oxnard GR, Binder A, Janne PA. New targetable oncogenes in non-small-cell lung cancer. Journal of clinical oncology: official journal of the American Society of Clinical Oncology. 2013; 31:1097-1104.

11. Rimkunas VM, Crosby KE, Li D, Hu Y, Kelly ME, Gu TL, Mack JS, Silver MR, Zhou X, Haack H. Analysis of receptor tyrosine kinase ROS1-positive tumors in non-small cell lung cancer: identification of a FIG-ROS1 fusion. Clin Cancer Res. 2012; 18:4449-4457.

12. Rikova K, Guo A, Zeng Q, Possemato A, Yu J, Haack H, Nardone J, Lee K, Reeves C, Li Y, Hu Y, Tan Z, Stokes M, Sullivan L, Mitchell J, Wetzel R, et al. Global survey of phosphotyrosine signaling identifies oncogenic kinases in lung cancer. Cell. 2007; 131:1190-1203.

13. McDermott U, Iafrate AJ, Gray NS, Shioda T, Classon M, Maheswaran S, Zhou W, Choi HG, Smith SL, Dowell L, Ulkus LE, Kuhlmann G, Greninger P, Christensen JG, Haber DA, Settleman J. Genomic alterations of anaplastic lymphoma kinase may sensitize tumors to anaplastic lymphoma kinase inhibitors. Cancer Res. 2008; 68:3389-3395.

14. Bos M, Gardizi M, Schildhaus HU, Heukamp LC, Geist T, Kaminsky B, Zander T, Nogova L, Scheffler M, Dietlein M, Kobe C, Holstein A, Maintz D, Buttner R, Wolf J. Complete metabolic response in a patient with repeatedly relapsed nonsmall cell lung cancer harboring ROS1 gene rearrangement after treatment with crizotinib. Lung Cancer. 2013; 81:142-143.

15. Chiari R, Buttitta F, Iacono D, Bennati C, Metro G, Di Lorito A, Iezzi M, Tiseo M, Mazzoni F, Cappuzzo F, Marchetti A, Crino L. Dramatic Response to Crizotinib in ROS1 Fluorescent In Situ Hybridization- and 
Immunohistochemistry-Positive Lung Adenocarcinoma: A Case Series. Clin Lung Cancer. 2014.

16. Shaw AT, Ou SH, Bang YJ, Camidge DR, Solomon BJ, Salgia R, Riely GJ, Varella-Garcia M, Shapiro GI, Costa DB, Doebele RC, Le LP, Zheng Z, Tan W, Stephenson P, Shreeve SM, et al. Crizotinib in ROS1rearranged non-small-cell lung cancer. N Engl J Med. 2014; 371:1963-1971.

17. Mazieres J, Zalcman G, Crino L, Biondani P, Barlesi F, Filleron T, Dingemans AM, Lena H, Monnet I, Rothschild SI, Cappuzzo F, Besse B, Thiberville L, Rouviere D, Dziadziuszko R, Smit EF, et al. Crizotinib Therapy for Advanced Lung Adenocarcinoma and a ROS1 Rearrangement: Results From the EUROS1 Cohort. J Clin Oncol. 2015.

18. Shaw AT, Kim DW, Nakagawa K, Seto T, Crino L, Ahn MJ, De Pas T, Besse B, Solomon BJ, Blackhall F, Wu YL, Thomas M, O'Byrne KJ, Moro-Sibilot D, Camidge DR, Mok T, et al. Crizotinib versus chemotherapy in advanced ALK-positive lung cancer. N Engl J Med. 2013; 368:2385-2394.

19. Johnson TW, Richardson PF, Bailey S, Brooun A, Burke BJ, Collins MR, Cui JJ, Deal JG, Deng YL, Dinh D,
Engstrom LD, He M, Hoffman J, Hoffman RL, Huang Q, Kania RS, et al. Discovery of (10R)-7-amino-12-fluoro2,10,16-trimethyl-15-oxo-10,15,16,17-tetrahydro-2H-8,4(metheno) pyrazolo[4,3-h][2,5,11]-benzoxadiazacyclotetrad ecine-3-carbonitrile (PF-06463922), a macrocyclic inhibitor of anaplastic lymphoma kinase (ALK) and c-ros oncogene 1 (ROS1) with preclinical brain exposure and broadspectrum potency against ALK-resistant mutations. Journal of medicinal chemistry. 2014; 57:4720-4744.

20. Vogelstein B, Papadopoulos N, Velculescu VE, Zhou S, Diaz LA Jr., Kinzler KW. Cancer genome landscapes. Science. 2013; 339:1546-1558.

21. Kim HR, Kim DJ, Kang DR, Lee JG, Lim SM, Lee CY, Rha SY, Bae MK, Lee YJ, Kim SH, Ha SJ, Soo RA, Chung KY, Kim JH, Lee JH, Shim HS, et al. Fibroblast growth factor receptor 1 gene amplification is associated with poor survival and cigarette smoking dosage in patients with resected squamous cell lung cancer. J Clin Oncol. 2013; 31:731-737.

22. Beasley MB, Brambilla E, Travis WD. The 2004 World Health Organization classification of lung tumors. Seminars in roentgenology. 2005; 40:90-97. 